\title{
IMPORTANT ASPECTS OF GENDER-BASED VIOLENCE IN CONDITIONS OF ARMED CONFLICT IN UKRAINE AND POLICE RESPONSES
}

\author{
Kachynska Maryana \\ Ph.D, Post-Doctoral Researcher of \\ Kharkiv National University of Internal Affairs
}

\begin{abstract}
Kachynska M. Important aspects of gender-based violence in conditions of armed conflict in Ukraine and police responses.

The article is devoted to selected aspects of gender-based violence in the context of the armed conflict in Ukraineo and the police response to these cases. The author considers the international legal regulation of prevention and counteraction to gender-based violence in the conditions of armed conflicts. The provisions of UN Security Council Resolution №1325, adopted on 31 October 2000, and UN Security Council Resolution №1296, adopted on 19 April of the same year, were analyzed separately. It is noted that the risk group, which is the most vulnerable to genderbased, should include internally displaced persons. When this category of people changes their place of residence due to the armed conflict in eastern Ukraine, they need specialist help and support from the community they are moving to, and especially from government agencies, including the police. In most cases, a district police officer is a first contact officer who has complete information about the population in their area of service, their needs and characteristics. That is why the author points to the leading role of the district police officer among other police services and divisions in the field of timely detection of gender-based violence. The article develops an algorithm of actions for district police officers in case of detection of gender-based violence, which contains signs of a crime, reveals some aspects of proceedings in this category, as well as the use of coercive measures by police. The author considers the forms of interaction of a district officer with other state bodies of state power and local government, as well as the public in the field of prevention and counteraction to gender-based violence.
\end{abstract}

Key words: gender-based violence, armed conflict, police response, violence, victims, algorithm of actions, police officer, internally displaced persons, legal regulation, international agreements.

Качинська М. Важливі аспекти гендерного насильства в умовах збройного конфлікту в Украӥні та реакція поліції.

Стаття присвячена вибраним аспектам гендерно-обумовленого насильства в умовах збройного конфлікту в Україні та реагуванню поліції на ці випадки. Автор розглядає міжнародно-правове регулювання попередження та протидії гендерно-обумовленому насильству в умовах збройних конфліктів. Окремо проаналізовано положення Резолюції Ради Безпеки ООН №1325, що прийнята 31 жовтня 2000 року, та Резолюції Ради Безпеки ООН №1296, яка була ухвалена 19 квітня того ж року.

Звернуто увагу, що до групи ризику, яка є найбільш уразливою до гендерно-обумовленого слід віднести внутрішньо переміщених осіб. Коли означена категорія людей змінює місце свого проживання через збройний конфлікт на сході України, вони потребують особливої допомоги та підтримки від громади, до якої вони переїжджають, і особливо від державних органів, у тому числі від поліції. У більшості випадків дільничний офіцер поліції є офіцером першого контакту, який володіє повною інформацією про населення у зоні свого обслуговування, його потреби та характеристики. Саме тому, автор вказує на провідну роль дільниного офіцера поліції поміж інших служб і піроздлів поліції саме у сфері своєчасного виявлення гендерно-обумовленого насильства.

У статті детально розкрито алгоритм дій дільничних фіцерів поліції у випадку виявлення гендерно-обумовленого насильства, що містить ознаки злочину, розкрито окремі аспекти провадження у справах даної категорії, а також застосування заходів примусу поліцейськими.

Автор розглядає форми взаємодії дільничного офіцера із іншими державним органами державної влади та місцевого смоврядування, а також громадськістю у сфері попередження та протидії гендерно-обумовленому насильству.

Ключові слова: гендерно-обумовлене насильство, збройний конфлікт, реагування поліцейськими, насильство, потерпілі, алгоритм дій, поліцейський, внутрішньо-переміщені особи, правове регулювання, міжнародні доровори. 
Addressing the problem. It is well known that the international community pays considerable attention to preventing and combating gender-based violence. To this end, the UN General Assembly Resolution «Transforming our world: the 2030 Agenda for Sustainable Development» was adopted on 25 September 2015 [1]. Based on this Resolution, the national «Sustainable Development Goals: Ukraine» have been developed [2]. Achieving gender equality and empowering all women and girls is goal number 5. The Sustainable Development Goals seek to realize the rights of all people and to realize gender equality and empower all women and girls. They are integrated and indivisible and balance 3 aspects of sustainable development: economic, social, environmental [1].

Analysis of research and publications. The question of preventing and detecting gender-based and intimate partner violence generally and while armed conflict especially was analysed by: N.Anishchyk, O. Banduka, O.Dzafarova, A. Masymov, T. Melnyk, M.Krochyk, S.Ewchenko, L.Shevchenko, U.Novakovska, Y.Bienkovska, L.Kelly, Y. Kyzmenko, B.Blonska, A.Baida, O.Shapowalova, M.Legenka, V.Popil, and others. Nonetheless, given the large scale of gender-based violence in the period of armed conflict in Ukraine [3], there is a reasonable need to research gender-based violence in the conditions of armed conflict in Ukraine and police responses to that.

\section{Basic content}

The issue of the sharp increase in gender-based violence in the context of military conflict in the world in general and in Ukraine in particular has become common, whereby such cases are often covered in the media. On the territory of the anti-terrorist operation and adjacent regions, a significant increase in the number of registered cases of rape was recorded, the number of women victims of robberies and looting increased [4, p.4]. Manifestations of gender-based violence in conditions of armed conflict should include: rape, sexual harassment, sexual coercion, forced prostitution, domestic violence, prenatal selection, female infanticide. Manifestations of gender-based violence should include: female genital mutilation (also known as female circumcision), forced abortion, forced sterilization, forced marriage, forced pregnancy, honor based killings, sexual slavery, war rape [5].

Legal regulation of prevention and counteraction to gender-based violence in the conditions of armed conflict is regulated by the norms of a number of international conventions to which Ukraine has acceded, among which are:

Geneva Convention relative to the Treatment of Prisoners of War [6];

Convention for the Amelioration of the Condition of the Wounded and Sick in Armed Forces [7];

Convention on the Amelioration of the Condition of the Wounded, Sick and Shipwrecked in the Armed Forces at Sea [8];

Convention for the Protection of Civilian Persons in Time of War [9];

Convention on the Prohibition of the Development, Production, Stockpiling, Use of Chemical Weapons and on Their Destruction [10];

UN Security Council Resolutions 1325 and 1296.

Consider in more detail the provisions of certain international instruments governing the prevention and combating of gender-based violence in armed conflict, namely Resolution 1325, adopted by the UN Security Council on 31 October 2000. Its provisions state the following:

- countries should ensure greater participation of women at all levels of decision-making in national, regional, international institutions and mechanisms for conflict prevention, management and resolution;

- calls on all actors to take a gender-sensitive approach to the coordination and implementation of peaceful measures, including:

a) The special needs of women and girls for repatriation and resettlement, including rehabilitation, reintegration and post-conflict reconstruction;

b) measures aimed at supporting women's peace initiatives, local conflict resolution processes, and involving women in the mechanism for implementing peace agreements;

c) Measures to protect and respect the human rights of women and girls, in particular with regard to the constitution, suffrage, police and the judiciary.

The provisions of Resolution 1325 draw attention to the need for the parties to military conflicts to take special measures to protect women and girls from gender-based violence, especially rape, other forms of sexual abuse, and other forms of violence [11].

Resolution 1296 was adopted by the UN Security Council at its 4130th meeting on 19 April 2000. Attention is drawn to the fact that intentional actions against civilians, detainees, systematic, blatant and widespread violations of international humanitarian law and human rights standards in situations of armed conflict pose a threat to international peace and security. Emphasis is placed on the importance of compliance with the above-mentioned norms, as well as the right of refugees and the provision of appropriate training for such rights concerning children and gender issues [12]. 
The risk group for those most vulnerable to gender-based violence should include internally displaced persons. When they change their place of residence due to the armed conflict in eastern Ukraine, they need special help and support from the community to which they have moved, and especially from government agencies, including the police. A district police officer is in many cases a first contact officer who has complete information about the population in his service area, their needs and characteristics. That is why, in our opinion, a district police officer is the most effective among other police officers in identifying victims among internally displaced persons and taking timely and appropriate responses. Therefore, it is appropriate to single out the algorithm of actions of a district police officer in identifying cases of gender-based violence that contain signs of crime among internally displaced persons.

Algorithm of actions of a district police officer in case of detection of gender-based violence that qualify as a crime:

- takes all measures to stop the mentioned violence. For example, in the event of a rape, the employee must verbally demand that the violence be stopped. In case of disobedience to the lawful requirements of the police officer, he is authorized on the basis of the provisions of the Law of Ukraine "On the National Police" to use physical force, special means and in cases provided by law firearms. The police officer must notify the immediate management and other statutory officials of the application of these measures;

- provides medical care to both the victim and the offender, in case of need;

- explains to the victim his / her rights in accordance with the current legislation, as well as the possibility of receiving assistance from state, including Mobile Brigades of social and psychological assistance to victims and public organizations by phone. $0-800-500-335$ or from mobile 116123. In order to ensure a safe place of residence and provide comprehensive assistance, the victim may go to a shelter for persons who have suffered from domestic violence and / or gender-based violence;

- accepts the application or notification (informs the applicant of his constitutional rights and obligations, the right not to testify against himself and his relatives; the right to defense, etc., including notifying of a knowingly false report of a crime under Article 383 Of the Criminal Code of Ukraine) and enters information into the Journal of Unified Accounting [13], Unified Register of Pre-Trial Investigations and Unified State Register of Domestic and Gender-Based Violence [14];

- transmits material to investigative units;

- informs not later than one day the relevant territorial subdivisions of the Ministry of Social Policy, the relevant bodies of district state administrations and local self-government about the revealed facts of gender-based violence in compliance with the legal regime of information with limited access;

- in order to protect the victim from the unlawful influence of the offender, the police officer explains the legal procedure for issuing a restrictive order.

In order to protect the victim from the offender who has committed or may commit gender-based violence, the court may issue a restrictive order against the offender for a period of 1 to 6 months. The right to apply to the court upon receipt of the said order has: - the injured person or his representative; - in case of gender-based violence against a child - parents or other legal representatives of the child, relatives of the child (grandmother, grandfather, adult brother, sister), stepmother or stepfather of the child, as well as the guardianship authority [15].

The court hears the case on the issuance of a restraining order within 72 hours from the moment of receipt of the application for issuance of the specified instruction. Court costs related to this category of cases are reimbursed by the state. The court, by a restrictive order, has the power to impose one or more of the following measures to temporarily restrict the rights of the offender or to impose the following obligations on him:

- prohibition to be in the place of joint residence (stay) with the injured person;

- elimination of obstacles to the use of property that is the object of the right of joint ownership or personal private property of the victim;

- restriction of communication with the injured child; - prohibition to approach a certain distance to the place of residence (stay), study, work, other places of frequent visits by the victim;

- prohibition to search for the injured person personally and through third parties, if he / she is in a place unknown to the offender, to persecute him / her and to communicate with him / her in any way;

- prohibition of correspondence, telephone conversations with the victim or contact with him through other means of communication in person and through third parties [15].

In case of intentional non-compliance by a person against whom a restrictive prescription of restrictions or obligations imposed on him, the person will be prosecuted under Article 390-1 «Failure to comply with restrictive measures, restrictive instructions or failure to pass the program for offenders» of the Criminal Code of Ukraine. The judge informs the police department at the place of residence (stay) of the victim to take the offender for preventive registration. 
Summarizing the above, we can indicate the following. Nowadays for Ukraine the question of gender-based violence in the conditions of armed conflict is an important issue. Ukraine joined to a numerous international convention on mentioned matters. The author of this paper has developed the innovative district police officer action algorithm in cases of gender-based violence that qualify as a crime based on the legal norms of Ukraine.

\section{References:}

1. Transforming our world: the 2030 Agenda for Sustainable Development. <https://sustainabledevelopment.un.org/ post2015/transformingourworld>. accessed 30 July 2021.

2. Презентовано Національну доповідь «Цілі Сталого Розвитку: Україна». <http://academy.gov. ua/?lang=ukr\&tip=osn\&page=2\&tipn=News\&newsid=1227\&designtype=blank_page> accessed 30 July 2021.

3. Survivors of gender-based violence in the Eastern Ukraine regions affected by armed conflict may have to face a compromised access to much needed psychosocial assistance and health services. <https://reliefweb.int/report/ukraine/ survivors-gender-based-violence-eastern-ukraine-regions-affected-armed-conflict-may>. accessed 30 July 2021.

4. Гендерно-обумовлене насильство в регіонах, які постраждали від конфрлікту. За результатами дослідження: Київ.2015. <https://www.humanitarianresponse.info/sites/www.humanitarianresponse.info/files/documents/files/final_ukr_ report.pdf >. accessed 30 July 2021.

5. Gender-based violence: Gender Trust. <http://www.gendertrust.org.uk/gender-based-violence/>. accessed 30 July 2021.

6. Женевська конвенція про поводження із військовополоненими : міжнародний документ від 12 серпня 1949 року. <https://zakon.rada.gov.ua/laws/show/995_153>. accessed 30 July 2021.

7. Конвенція про поліпшення долі поранених і хворих у діючих арміях : міжнародний документ від 12 серпня 1949 року. <https://zakon.rada.gov.ua/laws/show/995_151/>. accessed 30 July 2021.

8. Конвенція про поліпшення долі поранених, хворих та осіб, які зазнали корабельної аварії, зі складу збройних сил на морі : міжнародний документ від 12 серпня 1949 року. <https://zakon.rada.gov.ua/laws/show/995_152>. accessed 30 July 2021.

9. Конвенція про захист цивільного населення під час війни : міжнародний документ від 12 серпня 1949 року.<https://zakon.rada.gov.ua/laws/show/995_154>. accessed 30 July 2021.

10. Конвенція про заборону розробки, виробництва, накопичення, застосування хімічної зброї та про ії знищення : міжнародний документ від 13 січня 1993 року. <https://zakon.rada.gov.ua/laws/show/995_182>. accessed 30 July 2021.

11. Резолюція 1325 (2000): міжнародний документ від 31 грудня 2000 року. <https://zakon.rada.gov.ua/laws/ show/995_669.>. accessed 30 July 2021.

12. Резолюція 1296 (2000) : міжнародний документ від 19 квітня 2000 року. <https://zakon.rada.gov.ua/laws/ show/995_434>. accessed 30 July 2021.

13. Про затвердження Порядку ведення єдиного обліку в органах (підрозділах) поліції заяв і повідомлень про кримінальні правопорушення та інші події : наказ МВС України №100 від 08 лютого 2019 року. <https://zakon.rada. gov.ua/laws/show/z0223-19>. accessed 30 July 2021.

14. Про запобігання та протидію домашньому насильству : Закон України від 07 грудня 2017 року.< https://zakon. rada.gov.ua/laws/show/2229-19\#n27>. accessed 30 July 2021.

15. Про забезпечення рівних прав та можливостей жінок та чоловіків : Закон України від 08 вересня 2005 року. <https://zakon.rada.gov.ua/laws/show/2227-19>. accessed 30 July 2021.РОЗДІЛ 12 ФІЛОСОФІЯ ПРАВА 